\title{
Influence of bone-bed preparation shape on the primary stability of conical and cylindrical implants.
}

\author{
Paweł Nieckula, Piotr Wychowański, Karolina Szaniawska, Andrzej Wojtowicz \\ Department of Oral Surgery, Medical University of Warsaw
}

\section{Introduction}

Primary stability of dental implants depends on several factors, including implant length and diameter, macro- and microstructure, quality and quantity of the host bone, and size of bone preparation. None of previous studies has reported data assessing the effect of the impact of the shape of the drill used for bone bed preparation, such as tapered (conical) drills, cylindrical drills, or the method of preparation such as gradual preparation [1-9].

\section{Aim}

The aim of the study is to present the differences in primary stabilization of dental implants depending on implant type and the technique of the implant cradle preparation.

\section{Materials and Methods}

AB Dental (Israel) tapered (conical) and cylindrical implants of different length $(8 \mathrm{~mm}, 11,5 \mathrm{~mm}, 16 \mathrm{~mm})$ and diameter $(3,75 \mathrm{~mm}, 4,2 \mathrm{~mm}, 6 \mathrm{~mm})$ were used. The implants cradles were prepared in three different ways:

1. cylindrical preparation - using cylindrical drills in the dimension adjustable to the producer's recommendation - the diameter of implants' cradle was $15 \%$ less than the implants diameter.

2. conical preparation - using conical drills (a drill convergence is $12 \%$ ) in the dimension adjustable to the producer's recommendation - the diameter of implants' cradle was $15 \%$ less than the implants diameter.

3. gradual preparation - using cylindrical drills and all of them performed cradles full length without the last two ones - the former prepared the cradle only on their two thirds, whereas the latter only on one third.

Together 216 implants' cradles were performed - six cylindrical cradles for each tapered and each cylindrical implants, three conical cradles for each tapered and each cylindrical implants and three gradual cradles for each tapered and each cylindrical implants. The implants were inserted into isolated pork shoulders. Before implants' installation all pork shoulders were marked by gutta-percha points and scanned with computed tomography for compact bone thickness and bone density measurements as Hounsfield Units (HU). Next, HU were rescale on Misch classification of bone quality. Then an insertion torque by a dynamometric key, a primary stabilization with Periotest, Osstell Mentor - Resonance Frequency Analysis and pull-out test using a testing machine FP 100 were performed. All measurements were averaged and statistically analyzed using ANOVA procedure of SAS System 9.2 .

\section{Results}

1. Primary stability is better for implants of $6,0 \mathrm{~mm}$ in diameter than for implants of $3,75 \mathrm{~mm}$ and $4,2 \mathrm{~mm}$ in diameter (Table 1).

2. Primary stability is better for implants of $16 \mathrm{~mm}$ in length than for implants of 11,5 and $8 \mathrm{~mm}$ in length (Table 2).

3. Primary stability is better in bone D2 than D3 and D4 (Table 3).

4. Primary stability is better for tapered implants than for cylindrical ones (Table 4).

5. For tapered implants, the primary stability is better for conical and gradual bone-bed preparation than for cylindrical one (Table 4).

6. Cylindrical implants can be inserted only into cradles prepared using cylindrical drills.

\section{Conclusions}

1. Primary stability of dental implants depends on implant's diameter and length, implant's shape, as well as on the quality, quantity of the host bone and the type of bone-bed preparation.

2. There is recommended to apply longer, wider and tapered implants to increase primary stabilization.

3. Conical or gradual cradle preparations allow to achieve better mechanical implant stability especially in cases of poor bone quality.

Table 1. Influence of implants' diameter on primary stability determined by diffrent methods (mean $\pm S D$ ).

\begin{tabular}{|c|c|c|c|c|c|}
\hline $\begin{array}{c}\text { Diameter } \\
{[\mathrm{mm}]}\end{array}$ & $\mathrm{n}$ & $\begin{array}{c}\text { Insertion } \\
\text { Torque [Ncm] }\end{array}$ & $\begin{array}{c}\text { PerioTest } \\
{[\mathrm{PTV}]}\end{array}$ & $\begin{array}{c}\text { Pull Out Test } \\
{[\mathrm{N}]}\end{array}$ & $\begin{array}{c}\text { Resonance } \\
\text { Frequency } \\
\text { Analysis } \\
{[\mathrm{ISO}]}\end{array}$ \\
\hline 3,75 & 54 & $49,3 \pm 0,5$ & $-6,1 \pm 0,2$ & $932,0 \pm 58,7$ & $79,5 \pm 0,7$ \\
\hline 4,2 & 54 & $49,4 \pm 0,4$ & $-6,2 \pm 0,1$ & $963,0 \pm 55,1$ & $80,5 \pm 0,6$ \\
\hline 6 & 54 & $50 \pm 0$ & $-6,5 \pm 0,1^{\mathrm{a}}$ & $1096,9 \pm 58,4^{\mathrm{b}}$ & $82,1 \pm 0,5^{\mathrm{c}}$ \\
\hline
\end{tabular}

Different from: $a-3,75(p=0,001)$ and $4,25(p=0,037) ; b-3,75(p=0,002)$ and $4,25(p=0,015) ; c-3,75$ $(p=0,000)$ and $4,25(p=0,022)$.

Table 2. Influence of implants` length on primary stability determined by diffrent methods (mean $\pm S D$ )

\begin{tabular}{|c|c|c|c|c|c|}
\hline $\begin{array}{c}\text { Length } \\
{[\mathrm{mm}]}\end{array}$ & $\mathrm{n}$ & $\begin{array}{c}\text { Insertion } \\
\text { Torque [Ncm] }\end{array}$ & $\begin{array}{c}\text { PerioTest } \\
{[\mathrm{PTV}]}\end{array}$ & $\begin{array}{c}\text { Pull Out Test } \\
{[\mathrm{N}]}\end{array}$ & $\begin{array}{c}\text { Resonance } \\
\text { Frequency } \\
\text { Analysis } \\
{[\text { ISO] }}\end{array}$ \\
\hline 8 & 54 & $49,1 \pm 0,5$ & $-6,0 \pm 0,1^{\mathrm{a}}$ & $847,7 \pm 55,5^{\mathrm{b}}$ & $78,6 \pm 0,6^{\mathrm{d}}$ \\
\hline 11,5 & 54 & $49,7 \pm 0,3$ & $-6,3 \pm 0,2$ & $987,9 \pm 58,1^{\mathrm{c}}$ & $80,9 \pm 0,6^{\mathrm{e}}$ \\
\hline 16 & 54 & $49,9 \pm 0,1$ & $-6,6 \pm 0,1$ & $1156,4 \pm 53,1$ & $82,5 \pm 0,5$ \\
\hline
\end{tabular}

Different from: $a-11,5(p=0,007)$ and $16,0(p=0,000) ; b-11,5(p=0,010)$ and $16,0(p=0,000) ; c-16,0$ $(p=0,002) ; d-11,5(p=0,001)$ and $16,0(p=0,000) ; e-16,0(p=0,023)$.

Table 3. Influence of bone density on primary stability determined by diffrent methods (mean $\pm S D$ ).

\begin{tabular}{|c|c|c|c|c|c|}
\hline $\begin{array}{c}\text { Type of } \\
\text { Bone }\end{array}$ & $\mathrm{n}$ & $\begin{array}{c}\text { Insertion } \\
\text { Torque [Ncm] }\end{array}$ & $\begin{array}{c}\text { PerioTest } \\
{[\mathrm{PTV}]}\end{array}$ & Pull Out Test [N] & $\begin{array}{c}\text { Resonance } \\
\text { Frequency } \\
\text { Analysis } \\
{[\text { ISO] }}\end{array}$ \\
\hline D2 & 37 & $50,0 \pm 0,0$ & $-7,0 \pm 0,1^{\mathrm{a}}$ & $1446,2 \pm 46,6^{\mathrm{c}}$ & $83,9 \pm 0,4^{\mathrm{e}}$ \\
\hline D3 & 72 & $50,0 \pm 0,0$ & $-6,4 \pm 0,1^{\mathrm{b}}$ & $1037,2 \pm 40^{\mathrm{d}}$ & $81,4 \pm 0,4^{\mathrm{f}}$ \\
\hline D4 & 53 & $48,7 \pm 0,6$ & $-5,6 \pm 0,2$ & $629,8 \pm 34,8$ & $77,4 \pm 0,7$ \\
\hline
\end{tabular}

Different from: $a-D 3(p=0,000)$ and $D 4(p=0,000) ; b-D 4(p=0,000) ; c-D 3(p=0,000)$ and $D 4(p=0,000) ; d-D 4$ $(p=0,000) ; e-D 3(p=0,000)$ and $D 4(p=0,000) ; f-D 4(p=0,000)$.

Table 4. Influence of implant type and type of bone- bed preparation on primary stability determined by diffrent methods (mean $+S D$ ).

\begin{tabular}{|c|c|c|c|c|c|}
\hline $\begin{array}{c}\text { Implant Type/Type of } \\
\text { Cradle Preparation }\end{array}$ & $\mathrm{n}$ & $\begin{array}{c}\text { Insertion } \\
\text { Torque } \\
{[\mathrm{Ncm}]}\end{array}$ & $\begin{array}{c}\text { PerioTest } \\
{[\mathrm{PTV}]}\end{array}$ & $\begin{array}{c}\text { Pull Out Test } \\
{[\mathrm{N}]}\end{array}$ & $\begin{array}{c}\text { Resonance } \\
\text { Frequency } \\
\text { Analysis } \\
{[\text { ISO }]}\end{array}$ \\
\hline $\begin{array}{c}\text { Cylindrical/Cylindrical } \\
\text { Preparation (CC) }\end{array}$ & 54 & $49,1 \pm 0,5$ & $-5,1 \pm 0,14^{\mathrm{a}}$ & $744,2 \pm 44,33^{\mathrm{b}}$ & $77,5 \pm 0,74^{\mathrm{d}}$ \\
\hline $\begin{array}{c}\text { Tapered/Cylindrical } \\
\text { Preparation (TC) }\end{array}$ & 54 & $49,6 \pm 0,4$ & $-6,8 \pm 0,1$ & $901,9 \pm 48,9^{\mathrm{c}}$ & $81,3 \pm 0,4^{\mathrm{e}}$ \\
\hline $\begin{array}{c}\text { Tapered/Tapered } \\
\text { Preparation (TT) }\end{array}$ & 27 & $50,0 \pm 0,0$ & $-6,9 \pm 0,1$ & $1361,9 \pm 70,5$ & $83,7 \pm 0,5$ \\
\hline $\begin{array}{c}\text { Tapered/Gradual } \\
\text { Preparation (TGP) }\end{array}$ & 27 & $50,0 \pm 0,0$ & $-6,9 \pm 0,1$ & $1329,8 \pm 61,6$ & $82,8 \pm 0,6$ \\
\hline
\end{tabular}

Different from: $a-T C(p=0,000)$ and TT $(p=0,000)$ and TGP $(p=0,000) ; b-T C(p=0,006)$ and TT $(p=0,000)$ and TGP $(p=0,000) ; c-T T(p=0,000)$ and TGP $(p=0,000) ; d-T C(p=0,000)$ and TT $(p=0,000)$ and TGP $(p=0,000)$; $\mathrm{e}-\mathrm{TT}(\mathrm{p}=0,011)$

\section{References}

Anil S, Aldosari AA. Impact of bone quality and implant type on the primary stability: an experimental study using bovine bone. J Oral Implantol. 2015 Apr;41(2):144-8.

Barikani H, Rashtak S, Akbari S, Badri S, Daneshparvar N, Rokn A. The effect of implant length and diameter on the primary stability in different bone types. J Dent (Tehran). 2013 Sep;10(5):449-55.

Bataineh AB, Al-Dakes AM. The influence of length of implant on primary stability: An in vitro study using resonance frequency analysis. $J$ Clin Exp Dent. 2017 Jan 1:9(1):e1-e6.

Bilhan $H$, Geckili $O$ Mumcu $E$, Bozdag $E$, Sünbüloğlu $E$, Kutay $O$. Influence of surgical technique mplant shape and diameter on the primary stability in cancellous bone. J Oral Rehabil. 2010 Dec;37(12):900-7.

5. Elias CN, Rocha FA, Nascimento AL, Coelho PG. Influence of implant shape, surface morphology, surgical technique and bone quality on the primary stability of dental implants. J Mech Behav Biomed Mater. 2012 Dec;16:169-80.

6. Molly L. Bone density and primary stability in implant therapy. Clin Oral Implants Res 2006 Oct:17 Suppl 2:124-35.

Moon SH, Um HS, Lee JK, Chang BS, Lee MK. The effect of implant shape and bone preparation on primary stability. J Periodontal Implant Sci. 2010 Oct:40(5):239-43.

Tabassum A, Meijer GJ, Walboomers XF, Jansen JA. Evaluation of primary and secondary stability of titanium implants using different surgical techniques. Clin Oral Impl Res 2014; 25: 487-492.

Valente ML, de Castro DT, Shimano AC, Lepri CP, dos Reis AC. Analysis of the influence of implan (n) of primary stability using the correlation of multiple methods. Clin Oral Investig. 2015 Nov:19(8):1861-6. 